\title{
Selective Search, Sectoral Patterns, and the Impact on Product Innovation Performance
}

\author{
Köhler, Christian; Sofka, Wolfgang; Grimpe, Christoph
}

\author{
Document Version \\ Accepted author manuscript \\ Published in: \\ Research Policy \\ DOI: \\ 10.1016/j.respol.2012.03.020 \\ Publication date: \\ 2012 \\ License \\ CC BY-NC-ND
}

Citation for published version (APA):

Köhler, C., Sofka, W., \& Grimpe, C. (2012). Selective Search, Sectoral Patterns, and the Impact on Product Innovation Performance. Research Policy, 41(8), 1344-1356. https://doi.org/10.1016/j.respol.2012.03.020

Link to publication in CBS Research Portal

\section{General rights}

Copyright and moral rights for the publications made accessible in the public portal are retained by the authors and/or other copyright owners and it is a condition of accessing publications that users recognise and abide by the legal requirements associated with these rights.

\section{Take down policy}

If you believe that this document breaches copyright please contact us (research.lib@cbs.dk) providing details, and we will remove access to the work immediately and investigate your claim.

Download date: 26. Apr. 2023
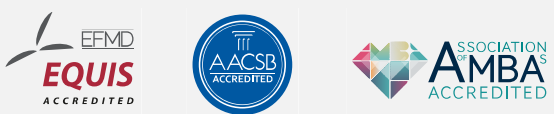


\section{Selective Search, Sectoral Patterns, and the Impact on Product Innovation Performance}

\section{Christian Köhler, Wolfgang Sofka, and Christoph Grimpe}

Journal article (Post print version)

This article was originally published in Research Policy, Vol. 41, Nr. 8, 2012, s. 1344-

1356. First published online: April 13, २०12.

DOl: 10.1016/j.respol.2012.03.020

Uploaded to Research@CBS: March २०16

(C) 2016. This manuscript version is made available under the CC-BY-NC-ND 4.0 license http://creativecommons.org/licenses/by-nc-nd/4.0/ 


\section{Selective Search, Sectoral Patterns, and the Impact on}

\section{Product Innovation Performance}

Christian Köhler ${ }^{a}$, Wolfgang Sofka ${ }^{b}$ and Christoph Grimpe ${ }^{c}$

${ }^{a}$ ZEW Centre for European Economic Research, L7, 1, 68169 Mannheim, Germany, christian.koehler@zew.de

${ }^{\mathrm{b}}$ Department of Organisation and Strategy, CentER, CIR, Tilburg University, Postbus 90153, 5000 LE Tilburg, the Netherlands, w.e.j.sofka@uvt.nl

c Copenhagen Business School, Kilevej 14A, 2000 Frederiksberg, Denmark, cg.ino@cbs.dk

Corresponding author:

Christoph Grimpe

Phone: $+45 / 3815 / 2530$

Fax: $+45 / 3815 / 2540$

Published in Research Policy, Vol. 41(8), 1344-1356. The final version can be found at http://www.sciencedirect.com/science/article/pii/S0048733312000819 


\title{
Selective Search, Sectoral Patterns, and the Impact on
}

\section{Product Innovation Performance}

\begin{abstract}
The shift towards more open and interconnected innovation activities has been a major topic in recent academic and practitioner discussions. Firms must connect their in-house R\&D activities with external partners, such as leading customers or universities, to increase the effectiveness of their innovation activities. Hence, management needs to define where to search for valuable knowledge in its environment. In this paper we argue that knowledge search has to reflect the heterogeneity of various knowledge sources with regard to the knowledge they can provide and how these sources can be activated. We hypothesize that search strategies driven by science, suppliers and the product market will contribute differently to innovation success with new-to-market versus imitated products. Moreover, we explore the effect of these types of knowledge search within different sectoral patterns of innovation. Our empirical analysis rests on a sample of almost 5,000 firms from five Western European countries. The results support our hypotheses and highlight the potentials and shortcomings of different types of knowledge search.
\end{abstract}

Keywords: Knowledge search, sectoral innovation patterns, new-to-market innovation, imitation

JEL-Classification: L60, O32 


\section{$1 \quad$ Introduction}

Research has frequently shown that firm success in technology-driven industries critically depends on the ability to invent and commercialize innovative technology embodied in new products (e.g., Katila, 2002; Katila and Ahuja, 2002). In this respect, firms with the ability to create new technological knowledge have been praised for generating knowledge internally and combining it with external knowledge sources (Rosenkopf and Nerkar, 2001). However, the process of identifying knowledge to be integrated into the organization's own knowledge base requires that firms deliberately search for and reach out to promising knowledge sources. Search has been characterized as the fundamental mechanism enabling firms to learn, evolve and refocus the organizational knowledge base. This goes beyond "local search", which assumes that research and development (R\&D) activities are connected to the firm's previous R\&D (Nelson and Winter, 1982). The literature has emphasized the importance for firms of moving beyond local search and reconfiguring the existing knowledge base (Kogut and Zander, 1992; Teece et al., 1997). In fact, the type of knowledge search and the defining direction and priority of boundary-spanning search activities have been found to substantially impact innovation performance (Katila, 2002; Katila and Ahuja, 2002; Laursen and Salter, 2006)

In this paper, we shed new light on the relationship between the type of knowledge search of a firm and its innovation performance. We propose that innovation management requires a more nuanced understanding of the nature and effects of knowledge search to implement them successfully. Prior research has largely focused on the dimensions of overall breadth and depth (e.g. Laursen and Salter, 2006). We argue that the description of knowledge search along its breadth and depth underestimates the degree of heterogeneity among the various knowledge sources they encompass. Instead, we suggest that the choice of a type of knowledge search is a selective process. Management will choose certain directions for the 
firms’ knowledge search that target particular knowledge sources (e.g., product market, science, suppliers).

Based on this conceptualization of selectivity in the knowledge sources that firms target through their particular search, we focus on the implications for a firm's success with new product introductions, thereby leaving out potential effects on other types of innovation like process or organizational innovations. In this respect, we suggest that these targeted types of knowledge search differ with regard to whether they generate new-to-market innovations or imitations, i.e. new-to-firm only. Imitated product innovations are distinctively different from new-to-market innovations in their degree of novelty. Imitations refer to existing products, services or processes that are adapted by the focal firm, for example through observing or reverse-engineering competitors' innovations. They could be refined to reinforce their ability to create value for the firm (Ettlie, 1983) or to improve and exploit existing technological trajectories (Gatignon et al., 2004). Contrary to imitations, new-to-market innovations are novel in the sense that they initially do not have a directly competing innovation. Distinguishing between both types of innovation output is important for at least two reasons. First, many studies on innovation focus on patents as output measures that reflect new-tomarket innovations because the patent office requires a certain "innovative step" in the novelty of an innovation for it to qualify for a patent application. Nevertheless, a significant amount of business R\&D is directed towards imitations. Second, the role of search for external knowledge may be substantially different depending on the type of innovation output the firm seeks to achieve.

Moreover, existing research has mostly focused on the manufacturing sector and, more specifically, on high-technology industries. Identifying how firms learn and how their knowledge evolves, though, should not be limited to manufacturing industries, particularly given the increasing importance of service sectors for most modern economies. Therefore, we 
adopt a novel typology of sectoral patterns of innovation developed by Castellacci (2008, 2010), which provides an integrated view of innovation characteristics in both manufacturing and services industries. The idea of a sectoral taxonomy is based on Pavitt's (1984) seminal contribution to highlight major features of the innovation processes and the distinct trajectories followed by industrial sectors. It is therefore fitting to integrate the role of search into particular sectoral patterns of innovation. Both the distinction between imitation and new-to-market innovation output and the sectoral pattern of innovation have been largely neglected in the extant discussion of knowledge search (e.g. Katila and Ahuja, 2002; Laursen and Salter, 2006; Rosenkopf and Nerkar, 2001), which is why they warrant further investigation.

While we derive hypotheses for the effects of particular types of knowledge search on the two types of innovation output, we choose an exploratory approach, i.e. no ex-ante hypotheses, for differences of these effects within certain sectoral patterns of innovation. Our empirical study is based on a comprehensive dataset of 4,933 manufacturing and service firms from five Western European countries. The data include measures on commercialized innovations, which can be considered superior to patents, an intermediary innovation output and typically only relevant in certain industries (Griliches, 1990). Moreover, the sample from five European countries provides close to representative information on manufacturing and service firms in major Western European economies.

The remainder of the paper is organized as follows. The next section details our theoretical framework to develop our hypotheses. Section 3 describes our empirical methods. Results are presented and discussed in the subsequent two sections. Section 6 concludes with limitations of our study and implications for further research. 


\section{Theoretical framework}

\subsection{The role of search for innovation performance}

It is widely accepted that a firm's ability to innovate is tied to the pool of knowledge available within the organization (e.g., Subramaniam and Venkatraman, 2001). The generation of new knowledge has traditionally been connected to a firm's in-house research and development (R\&D) activities. Recent literature, however, points to the advantages of combining internal investments with external resources (e.g. Cassiman and Veugelers, 2006) to benefit from complementarities. In other words, firms have begun to open up their innovation processes to external knowledge. This trend of so-called “Open Innovation” allows firms to access and exploit external knowledge while internal resources are focused on core activities (Chesbrough, 2003). Both supply and demand oriented aspects put firms in a position to acquire knowledge externally. On the one hand, there is an increasing availability of external knowledge, e.g. from universities, customers and specialized suppliers (e.g., von Hippel, 1988; Link and Scott, 2005; Perkmann and Walsh, 2007; van Echtelt et al., 2008). On the other hand, firms are pushed to find new sources for external innovation impulses because of increasing competitive pressures, shorter product life cycles as well as technological opportunities beyond their traditional fields of expertise (e.g., Calantone et al., 1997; Chatterji, 1996; Kleinschmidt and Cooper, 1988; Ojah and Monplaisir, 2003). Several studies have identified positive performance effects of incorporating external knowledge (e.g.

Gemünden et al., 1992; Laursen and Salter, 2006; Love and Roper, 2004).

A crucial element in the open innovation activities of firms is a firm's search for external knowledge. A firm’s external knowledge search encompasses an “organization’s problemsolving activities that involve the creation and recombination of technological ideas" (Katila and Ahuja, 2002, p. 1184). Consequently, investments in problem-solving activities should 
result in favorable combinations and linkages of users, suppliers and other relevant actors in the innovation system. Laursen and Salter (2006) discuss the concepts of breadth and depth as important factors in a firm's search. Leiponen and Helfat (2010) complement this view by extending the concept of breadth to innovation objectives. They find that the breadth of knowledge sources and of innovation objectives positively influence innovation success at the firm level. Although a broader set of external sources and innovation objectives reduces the risk of unexpected developments, it has to be taken into account that a firm is constrained in terms of the capacity to absorb external knowledge (Cohen and Levinthal, 1989, 1990). These limitations include the level of overall attention a firm's management can dedicate to these activities (Ocasio, 1997). A proper search for external knowledge should therefore concentrate on certain external sources as a vast number of information sources would hamper selection and in-depth exploration processes (Koput, 1997). Contrary to search breadth, search depth can be described as the extent to which firms draw deeply from various external sources for innovation impulses (Laursen and Salter, 2006). Both breadth and depth depict a firm's openness to external innovation impulses (Chesbrough, 2003). Studying the UK manufacturing sector, Laursen and Salter (2006) find that the relationship between search breadth and depth and innovation performance has an inverted U-shape. This means that while search efforts initially increase a firm's performance, there is a trade-off from “oversearching” the environment. At a certain threshold it requires too much management attention (Ocasio, 1997) and has a negative effect on innovation performance.

In a similar vein, Katila and Ahuja (2002) focus on search depth and search scope in the search and problem-solving activities of firms in the robotics industry. Contrary to Laursen and Salter (2006), they define search depth as the extent to which a firm reuses existing internal knowledge, while search scope indicates how widely a firm explores externally available knowledge. The latter largely corresponds to search breadth as defined by Laursen 
and Salter (2006). However, Katila and Ahuja's (2002) definition of search depth puts greater emphasis on exploiting the established knowledge base within the firm. Consistent with the results of Laursen and Salter (2006), Katila and Ahuja (2002) observe an inverted U-shaped relationship between the search effort and innovation performance, which again points to the negative consequences of too extensive search activities. They also present evidence that the interaction of search breadth and depth is positively related to innovation performance because it increases the uniqueness of resource recombinations: A deep understanding of firm-specific knowledge assets that is extended towards a new application (scope) creates unique and more valuable combinations of resources.

\section{$2.2 \quad$ Selection of knowledge sources}

The conceptualization of a firm's knowledge search along the dimensions of its breadth and depth implies that the targeted knowledge is largely homogeneous with regard to its source. Following Laursen and Salter (2006), a firm focusing, for example, solely on lead customer knowledge may be assumed to conduct a knowledge search that is as broad and deep as a firm that concentrates its search for knowledge completely on universities. This assumption may be correct once the external knowledge has entered the firm and is already assimilated with existing knowledge stocks. However, we expect the homogeneity assumption of the knowledge of any firm's knowledge search to fail as long as the knowledge remains unidentified outside the firm's boundaries. This “scanning” stage is crucial for the successful implementation of external knowledge sourcing (Doz et al., 2001). Todorova and Durisin (2007) point out that the transformation of external knowledge is one of the most important steps for absorbing it. This reflects the fact that external knowledge can be assumed to be highly heterogeneous in nature. ${ }^{1}$

1 Typical categorizations of heterogeneity in knowledge include distinguishing between tacit and formal (e.g., Cowan et al., 2000; Dyer and Hatch, 2004; Polanyi, 1967), specific and generic (e.g., Breschi et al., 2000), 
We argue that management will define a firm's search for external knowledge based on its source. Put simply, we propose that management choice is not between breadth and depth; rather it provides certain directions for the firm's own research efforts. These directions should reflect the potential value of a knowledge source and how easily it can be accessed and transferred. Focus is thus not so much on the recipient firm's absorptive capacity but rather on the value of the knowledge source. The ultimate, economic value for the searching firm is exante not clear. The value is significantly lower if the sourced knowledge is technologically premature, reflects myopic perspectives or is also readily available to competitors (Frosch, 1996; Katila and Chen, 2008; Mansfield, 1986). Hence, the ultimate value assessment of an external knowledge source depends on whether the knowledge will lead to a successful invention, whether this invention will generate economic returns and whether these returns can be appropriated by the firm making the investment in the first place. The perception of these factors can be expected to influence the selection of a particular type of knowledge search (March and Shapira, 1987). In the following, we will discuss major differences between the knowledge sources of the product market, science, and suppliers.

The product market side has received considerable attention particularly in the marketing literature as part of the "market orientation” of firms (for a review see Kohli and Jaworski, 1990). This broader conceptualization emphasizes a shift in corporate culture towards creating superior value for customers (e.g. Slater and Narver, 2000). Customers and competitors can be considered the primary elements of a product market driven knowledge search. Both groups are necessarily too important to be neglected as their actions have an immediate impact on a firm's sales. Impulses from both groups have been found to propel innovation success. Customers significantly contribute to product innovations even with a high degree of 
novelty (Lukas and Ferrell, 2000). Moreover, they are especially valuable as knowledge sources when their specific demands are anticipatory for larger market segments in the future (von Hippel, 1988; Beise-Zee, 2001). However, identifying these leading customers has been found to be challenging. Customer knowledge is oftentimes tacit, unarticulated and focused on the customer's own myopic needs (Frosch, 1996; von Zedtwitz and Gassmann, 2002). Literature has therefore cautioned managers not to focus reactively on customers’ immediate needs. It is necessary to balance this narrow “consumer-led” approach with proactive measures for identifying long-term latent customer needs (Ketchen et al., 2007; Slater and Narver, 1998, 1999).

Competitor knowledge is different with regard to its accessibility. Competitors operate in a similar market and technology context (Dussauge et al., 2000). Their knowledge is oftentimes embodied in the products or services available on the market. That makes it easier to identify relevant aspects and absorb them. However, it limits the opportunities for generating economic returns because of the reduced degree of novelty. In this respect, a market-oriented knowledge search is more likely associated with imitations or "me-too" products (Lukas and Ferrell, 2000). Knowledge accessed through such a search can be rather familiar and without a high degree of novelty. As a result, our first hypothesis reads:

Hypothesis 1: Market-driven search is stronger associated with imitation success than with new-to-market innovation success.

Science-driven search requires a different set of specialized competencies. Universities are the primary producers of fundamentally new knowledge and technology. The knowledge produced often has a high degree of novelty, which provides important business opportunities (e.g. Cohen et al., 2002). What is more, academic incentive systems for knowledge publication and sharing make university knowledge largely a public good (Perkmann and Walsh, 2007). However, university knowledge is frequently further removed from 
commercial application and requires substantial investments in development to commercialize it (Link et al., 2007; Siegel et al., 2004). Moreover, firms require specialized absorptive capacities to assess and transfer this type of knowledge. Assessing the full value of the often tacit and causally ambiguous knowledge may only be possible through joint research activities in which university and firm scientists develop a mutual understanding and language in practice over time (Laursen and Salter, 2006). Science-driven knowledge search should therefore be shaped by the competencies in the firm's own R\&D department (Asmussen et al., 2009). The skills as well as the personal networks of firm scientists and engineers developed through education and training (Adler and Kwon, 2002) are a necessary prerequisite.

A firm's search based on knowledge from universities or public research institutes can thus be assumed to provide highly novel knowledge and corresponding opportunities for commercialization (e.g. Cohen et al., 2002). Hence, university knowledge has the potential to lead to the generation of new-to-market innovations.

Hypothesis 2: Science-driven search is stronger associated with innovation success of new-to-market innovations than with imitation success.

Finally, suppliers have been characterized as an important driver for innovation success (e.g. Pavitt, 1984). On the one hand, firms may use suppliers to learn faster, accelerate the product development process and rely on resources created in a co-evolutionary relationship between the focal firm and its network of suppliers (Dyer and Hatch, 2004; van Echtelt et al., 2008). On the other hand, knowledge produced by suppliers is not necessarily unique since potential competitors may equally benefit from the supplier's expertise. Moreover, Kotabe (1990) finds that firms that rely heavily on supplier knowledge may lose relevant manufacturing process knowledge, which may cost the firm the opportunity to improve their manufacturing technology in a rapidly changing technological environment. As a result, the effects of 
supplier-driven knowledge search can be expected to affect imitation and new-to-market innovation equally.

Hypothesis 3: Supplier-driven knowledge search is equally associated with success of new-to-market innovations as well as imitations.

\subsection{Search and sectoral patterns of innovation}

Existing research on knowledge search that distinguishes between the manufacturing and the service sector is scarce. Most empirical analyses are either explicitly limited to firms in manufacturing (e.g. Laursen and Salter, 2006) or rely on patent statistics to trace knowledge flows (e.g. Katila and Ahuja, 2002). The latter approach is implicitly focused on manufacturing firms as several studies show that firms in manufacturing sectors are significantly more likely to patent than service firms (e.g. Arundel and Kabla, 1998; Harabi, 1995). Although a fairly rich body of literature on innovation in services has developed in recent years (for a recent review see Paswan et al., 2009), it has been argued that many studies actually lack relation to the well-established models for the study of innovation in manufacturing industries (Gallouj and Weinstein, 1997). Castellacci $(2008,2010)$ therefore calls for a more integrated view of the patterns that innovation activity takes in both manufacturing and services sectors. Our research responds to this call and explores, based on the sectoral taxonomy developed by Castellacci (2008), the importance of the different types of knowledge search for achieving either imitation or new-to-market innovation performance. Due to the novelty of the adopted taxonomy we will, however, not derive any ex-ante hypotheses on expected relationships within each of the sectoral patterns presented.

The sectoral taxonomy suggested by Castellacci (2008) identifies four main sectoral groups, which are defined along two dimensions: (1) their function in the economic system as a provider and/or recipient of advanced products, services and knowledge; and (2) their sectoral 
technological trajectory, which characterizes innovation activities. The technological trajectory can be seen as a pattern of “normal” problem solving activity (Dosi, 1982). The pattern is sectoral to the extent that industries differ significantly in their ability to exploit the dominant natural trajectories (Nelson and Winter, 1977). This implies that those sectors whose knowledge base is closely related to emerging technology fields enjoy higher growth prospects as they exhibit higher dynamism and technological opportunities. The well-known taxonomy developed by Pavitt (1984), which groups firms into four major patterns of innovation, builds on the idea that those patterns can be characterized by different technological trajectories. The supplier-dominated, scale-intensive, specialized suppliers, and science-based industries, as defined by Pavitt, however, focus on the manufacturing sector, thus neglecting the emergence of advanced services which are closely related to new technological trajectories. Examples include new services in the information and communications sectors which have opened up the way for future growth opportunities (Castellacci, 2008).

Instead of proposing, however, a new taxonomy of service industries to complement those used to characterize manufacturing industries (e.g., Miozzo and Soete, 2001), Castellacci (2008) puts emphasis on the interdependence and vertical linkages that bind together different groups of manufacturing and service sectors. Based on the two dimensions outlined above (vertical chains and technological content), he distinguishes between advanced knowledge providers (AKP), supporting infrastructural services (SIS), producers of mass production goods (MPG), and producers of personal goods and services (PGS). Both AKP and SIS are characterized as providing rather intermediate goods and services to other sectors while MPG and PGS assume a higher position in the vertical chain by providing rather final goods and services. In contrast to this, both AKP and MPG are characterized by a higher technological 
content than SIS and PGS, i.e. the former are able to develop new technologies internally to provide them to other sectors. $^{2}$

The role of search for achieving innovation performance within these four categories can consequently be expected to differ according to the sector's position in the vertical chain and the technological content. Market-driven knowledge search has been described as being conducive to accessing customer and competitor knowledge that, due to the lack of novelty, will lead to imitation rather than new-to-market innovation success. As MPG and PGS are classified as providing rather final goods and services to the market, closeness to customers and competitors is likely to be important. Market-driven knowledge search might therefore convey highly relevant knowledge for firms in these categories to achieve success with their innovations. However, due to the lack of novelty, it is likely to be the firm's ability to generate imitations that will benefit from this type of knowledge search.

Science-driven knowledge search, by contrast, can be assumed to provide highly novel knowledge and corresponding opportunities for commercialization. They should hence be more valuable to firms characterized by higher technological content like AKP and MPG. As a result, it is likely that those firms' innovation performance with market novelties will increase compared to those with imitations. Finally, supplier-driven knowledge search has been described as theoretically inconclusive with respect to the type of innovation performance it is likely to foster. On the one hand, knowledge from suppliers can be immediately relevant and even evolve in a co-evolutionary way together with the focal firm's knowledge and hence provide a head start over competitors. On the other hand, such knowledge can in principle also be accessed by competitors if they collaborate with the same

2 Castellacci (2008) moreover identifies two sub-groups per category: knowledge-intensive business services and specialized suppliers manufacturing (AKP), science-based manufacturing and scale-intensive manufacturing (MPG), network infrastructure services and physical infrastructure services (SIS), supplierdominated goods and supplier-dominated services (PGS). For ease of interpretation, these sub-groups will however be omitted from the following analysis. 
supplier, leading to less novelty in the innovation outcome. Consequently, the role that supplier-driven search will play within the four sectoral patterns is unclear and requires expost analysis.

\section{$3 \quad$ Empirical study}

\subsection{Data}

The empirical part of our study is based on cross-sectional data from the third Community Innovation Survey (CIS-3), which was conducted in 2001 under the co-ordination of Eurostat. The survey covers the innovation activities of enterprises in the EU member states (including some neighboring states) during a three-year period from 1998-2000. What is exceptional about CIS-3 is that it offers representative firm data from all EU member states, which are to a great extent relevant to the questions raised in our study. The micro data of CIS-3 also provide information on the two-digit industry code (NACE) of a firm. This means that it is possible to assign firms to different sectoral patterns of innovation. As the data are anonymized, it is impossible to identify single firms or to trace the exact answers back to the respective firms (Eurostat, 2005). The dataset we use in this study offers data for five Western European member states, which make up a sample of 4,933 observations of enterprises from the following countries: Belgium (636 firms), Germany (1,446 firms), Greece (332 firms), Portugal (489 firms) and Spain (2,030 firms). Sectoral patterns were identified based on the firms’ NACE 2-digit classification (Castellacci, 2008). Table 1 provides details on the industries represented in our analysis. 
Table 1: Industry breakdown

\begin{tabular}{|c|c|c|}
\hline Industry & NACE Code (Rev. 1.1) & Sectoral pattern \\
\hline \multicolumn{3}{|l|}{ Manufacturing } \\
\hline Food and tobacco & $15-16$ & Personal goods and services \\
\hline Textiles, clothing and leather & $17-19$ & Personal goods and services \\
\hline Wood / paper / publishing / printing & $20-22$ & Personal goods and services \\
\hline Chemicals (incl. pharmaceuticals) & 24 & Mass production goods \\
\hline Plastics / rubber & 25 & Mass production goods \\
\hline Glass / ceramics & 26 & Mass production goods \\
\hline Metals & $27-28$ & Mass production goods \\
\hline Machinery and equipment & 29 & Advanced knowledge providers \\
\hline Office and computing machinery & 30 & Mass production goods \\
\hline Electrical machinery and apparatus & 31 & Mass production goods \\
\hline Radio, TV and communication equipment & 32 & Mass production goods \\
\hline Medical, precision and optical equipment & 33 & Advanced knowledge providers \\
\hline Motor vehicles and trailers & 34 & Mass production goods \\
\hline Transport equipment & 35 & Mass production goods \\
\hline Manufacturing n.e.c. (e.g. furniture, sports equipment and toys) & $36-37$ & Personal goods and services \\
\hline \multicolumn{3}{|l|}{ Services } \\
\hline Wholesale trade and commission trade & 51 & Supporting infrastructure services \\
\hline Transport and storage (land, water, air) & $60-63$ & Supporting infrastructure services \\
\hline Post and Telecommunications & 64 & Supporting infrastructure services \\
\hline Financial intermediation & $65-67$ & Supporting infrastructure services \\
\hline Computer, engineering and $R \& D$ services & $72,73,74$ & Advanced knowledge providers \\
\hline
\end{tabular}

A major benefit of CIS-3 is that it provides direct, importance-weighted measures for a comprehensive set of variables for a firm’s innovation management (Criscuolo et al., 2005). General managers, heads of R\&D departments or innovation management are asked directly if and how they are able to generate innovations. Such immediate information on processes and outputs can be added to traditional measures for innovation such as patents (Kaiser, 2002; Laursen and Salter, 2006). That seems to be especially relevant for our research question as service firms have a lower propensity to patent their innovations. 
Innovation surveys like CIS rely on firms’ self-reporting. This might raise quality issues regarding administration, non-response and response accuracy (for a discussion see Criscuolo et al., 2005). However, the implementation of the survey is designed to limit possible negative effects. The fact that the survey is conducted via mail prevents certain shortcomings and biases of telephone interviews (for a discussion see Bertrand and Mullainathan, 2001). Moreover, the survey is accompanied by extensive pre-testing and piloting in various countries, industries and firms with regard to interpretability, reliability and validity (Laursen and Salter, 2006). In order to improve response accuracy, the questionnaire offers detailed definitions and examples.

\subsection{Variables and method}

\subsubsection{Measuring success of new-to-market innovations and imitations}

Several authors have introduced different concepts for measuring innovation success (for an overview see Hagedoorn and Cloodt, 2003). One possibility is to use innovation inputs (R\&D expenditures) as an indicator of innovation efforts and (indirectly) innovation success. Another way is to look at the outcome of innovative efforts, such as patents, new processes, services and/or products. The latter is the perspective that we choose for our study. Furthermore, we distinguish between new-to-market innovations and imitations by considering the degree of novelty. We refer to a product or service as a new-to-market innovation if it is new not just to the firm but also to its overall market. In contrast, we consider a product or service to be an imitation if it is new to the firm but has alternatives on the market.

The success of an innovation largely depends on market acceptance. For this reason we define innovation success as the share of sales achieved with products/services new to the market on the one hand and the share of sales achieved with products/services new to the firm 
on the other. ${ }^{3}$ For ease of presentation we will subsequently limit the terminology for innovation outputs to the terms "market novelties" for products and/or services new to the market and "firm novelties" for products and/or services new to the firm only. There is no implicit or explicit distinction between innovative products and services beyond the industry classification.

\subsubsection{Capturing knowledge search}

Measuring knowledge spillovers is a challenging task since they leave no paper trail. Several studies use patent statistics and subsequent citations to capture them (e.g., Galunic and Rodan, 1998; Rosenkopf and Nerkar, 2001). However, such an approach is not always appropriate as "not all inventions are patentable, not all inventions are patented” (Griliches, 1990, p. 1669). Moreover, the distribution of patenting firms is often heavily skewed. This is for example demonstrated by Bloom and van Reenen (2002). In their study, 72 percent of the sample of almost 60,000 patents by UK firms originates from just twelve companies. Patenting implies the disclosure and codification of knowledge in exchange for protection (Gallini, 2002). The majority of valuable knowledge may therefore never be patented. Moreover, patent statistics provide limited opportunities to identify distinct types of knowledge search because they do not offer any information on the relationships between the two firms identified in the patents (e.g. whether they are customers or competitors). Therefore, we use survey questions to gain information about external knowledge sources. Importance-weighted answers indicate the value of their contribution. More precisely, respondents are asked to evaluate the importance of the main sources for their innovation activities on a 4-point Likert scale ranging from "not used" to "high". We use information about seven different sources: suppliers, customers, competitors, universities, public research

3 Not all of a firm's "new to the market” products are necessarily "new to the world"; they may be new to the firm’s specific market only. 
institutes, professional exchanges (e.g. conferences), as well as exhibitions and fairs. In a similar setting, Laursen and Salter (2006) generate indices for the breadth and depth of a firm's knowledge search based on these questions. Breadth is measured as the number of different sources used while depth is measured as the number of highly important sources. We deviate from their approach in order to identify a firm’s targeted knowledge search.

We argue that R\&D managers develop targeted types of knowledge search with a certain direction. This is in contrast to Laursen and Salter (2006), who assume that knowledge search is defined on the basis of breadth and depth and thus ignore direction. We inspect the correlations between the several knowledge sources as shown in Table 2 and find that customers and competitors, universities and public research institutes, and suppliers, professional exchanges and exhibitions/fairs are correlated with each other. This observation provides grounds for the assumption that firms apply targeted knowledge searches (Sofka and Grimpe, 2010). We therefore apply a principal component factor analysis in order to identify underlying factors. The data appear to be suitable (Cronbach’s alpha scale reliability coefficient: 0.70; Kaiser-Meyer-Olkin measure of sampling adequacy: 0.69). We identify three factors with an eigenvalue greater than one. We conduct an orthogonal varimax rotation in order to interpret the factors with respect to their informational content. The orthogonality assumption of the factors is tested through a likelihood ratio test, which confirms the independence of all factors with an error probability far below one percent (Kaiser and Rice, 1974). Factor loadings identify three individual factors distinctively (above 0.69), as illustrated in Table 3. 
Table 2: Correlation matrix of knowledge sources

\begin{tabular}{|c|c|c|c|c|c|c|c|}
\hline & Supplier & Customer & Competitor & University & $\begin{array}{c}\text { Public } \\
\text { Research } \\
\text { Institute }\end{array}$ & $\begin{array}{l}\text { Professional } \\
\text { Exchange }\end{array}$ & $\begin{array}{c}\text { Exhibitions } \\
\text { and Fairs }\end{array}$ \\
\hline Supplier & 1 & & & & & & \\
\hline Customer & 0.118 & 1 & & & & & \\
\hline Competitor & 0.166 & 0.441 & 1 & & & & \\
\hline University & 0.132 & 0.208 & 0.175 & 1 & & & \\
\hline Public Research Institute & 0.130 & 0.171 & 0.144 & 0.571 & 1 & & \\
\hline Professional Exchange & 0.224 & 0.207 & 0.265 & 0.352 & 0.289 & 1 & \\
\hline Exhibitions and Fairs & 0.266 & 0.264 & 0.309 & 0.203 & 0.203 & 0.547 & 1 \\
\hline $\mathrm{N}$ & 4,933 & & & & & & \\
\hline
\end{tabular}

The retained factors reflect our conceptualization of knowledge search defined along specific search directions instead of rather broadly defined breadth and depth. The first factor is characterized by scientific contributions to innovation processes (public research institutes and universities). Therefore we will refer to this factor as "science-driven knowledge search". Suppliers, professional exchanges, and exhibitions/fairs load highly positive on the second factor. This is surprising at first sight as our theoretical argumentation is largely based on supplier interaction without taking into account professional exchanges or fairs in particular. Then again, supplier knowledge provides the highest level of uniqueness and Kaiser-MeyerOlkin measure (KMO) of any item in the factor analysis. This indicates that supplier knowledge is the defining influence behind factor 2. We suspect that fairs and professional exchanges serve as the contact points at which firms find and connect with potential suppliers and are therefore considered an element of search for this particular factor. Hence, we interpret this factor as “supplier-driven knowledge search”. Nevertheless, it should be kept in mind that it does not exclusively capture supplier knowledge but a broader conceptualization in which knowledge is made "accessible” (fairs, exhibitions, exchanges) or can be procured. In contrast, the third factor reflects a considerable contribution to innovation processes coming from the firms’ market environment (customers and competitors). We interpret this 
factor accordingly as "market-driven knowledge search”. We will use the three derived factor scales as focus variables to test our hypotheses empirically.

Table 3: Results of the principal component factor analysis: Factor loadings after varimax rotation

\begin{tabular}{lccccc}
\hline \hline & Factor 1 & Factor 2 & Factor 3 & Uniqueness & KMO $^{\mathrm{a}}$ \\
\hline Supplier & & 0.703 & & 0.505 & 0.851 \\
Customer & & 0.845 & 0.264 & 0.707 \\
Competitor & & 0.807 & 0.301 & 0.720 \\
University & 0.865 & & 0.224 & 0.647 \\
Public Research Institute & 0.869 & & 0.232 & 0.654 \\
Professional Exchange & & 0.698 & 0.369 & 0.712 \\
Exhibitions and Fairs & & & 0.331 & 0.695 \\
\hline Overall & & & & 0.695 \\
\hline \hline
\end{tabular}

Factor loadings below 0.5 are excluded from the table.

${ }^{a}$ Kaiser-Meyer-Olkin measure of sampling adequacy

\subsubsection{Control variables}

We include several control variables in our empirical model to account for other factors that may influence the estimation results. Obviously, the success of a firm's innovation activities depends crucially on the level of its investments in research and development. These in-house R\&D investments have been found to form a firm's absorptive capacity for identifying, assimilating and exploiting external knowledge (Cohen and Levinthal, 1989, 1990). Hence, we include R\&D intensity measured by $R \& D$ expenditures as a share of sales. Furthermore, valuable knowledge is often the result of accumulated R\&D over time, which typically requires a dedicated $R \& D$ department. We include a dummy control variable for whether the company performs R\&D continuously. As a firm’s innovation success may be affected by the availability of resources we control for a liability of size or smallness by adding the firm's sales from the start of the reporting period (1998) in logs. A firm's degree of internationalization is captured by the export intensity which is measured as ratio of exports to total sales. As our observations stem from various European countries, it is necessary to control for effects of the national regulation environment as well as peculiarities of the 
innovation system. This is done by incorporating country dummy variables into the regression. If a firm is part of a group, it can spread certain functions among subsidiaries or draw from their resources. We therefore add a dummy variable to control for this fact. In addition, some firms may only invest in process innovation. The innovation success of these activities cannot be accounted for. We thus add a dummy variable for process innovators.

\subsection{Estimation strategy}

In order to test the three hypotheses, we estimate two separate empirical models for both dependent variables: share of sales with firm novelties and share of sales with market novelties. As the dependent variables in all models are shares, they are censored between 0 and 1 with a significant fraction of observations having a value of zero. We address this issue by estimating Tobit models. For the exploratory part of our analysis we run the same estimations on subsamples representing the four sectoral patterns. The size of the overall sample allows for a sector-specific split with each subsample containing at least 800 observations. An alternative approach could have been to generate interaction terms between the type of knowledge search and the sectoral patterns. However, due to potential multicollinearity and difficulties in interpretation of multiplicative interactions in non-linear models, we opt for separate estimations (e.g. Salomon and Jin, 2010).

We benefit from a comprehensive dataset that does not limit the empirical findings to a particular firm size, industry or country setting. Then again, this induces additional layers of heterogeneity to the dataset, which may not be completely captured by control variables. Most standard regression models require homoscedasticity for consistent estimation results. ${ }^{4}$ That is, the variance of the random variable is assumed to be the same regardless of whether observations stem from large or small firms and of how they differ by industry or country. If

\footnotetext{
4 See Greene, 2002, p. 698-700, for details in the context of Tobit models.
} 
this is not the case, estimations might suffer from heteroscedasticity. Heteroscedastic datasets may lead to an underestimation of the variance in an empirical model and subsequently to a lower threshold for the identification of significant results. Given the nature of our dataset, we consider it necessary to test for homoscedasticity. We apply Likelihood ratio tests to check if firm size, industry and location of a firm cause heteroscedasticity. ${ }^{5}$ The results of the LR-test reject homoscedasticity in all model specifications. Thus we include firm size, country dummies and industry dummies in heteroscedastic regressions where we consider the variance $\sigma_{i}^{2}$ of observation $i$ to be of the form $\sigma_{i}=\sigma \exp \left(z_{i}^{\prime} a\right) . z$ represents the vector of variables in the heteroscedasticity term while $a$ denotes the vector of additional coefficients to be estimated. This correction allows for the estimation of heteroscedasticity-consistent coefficients.

In addition, we inspect the dataset for issues arising from multicollinearity by calculating both pair-wise correlations and variance inflation factors. The dataset shows no particularly high degree of multicollinearity by any conventionally applied standard in the literature (Chatterjee and Hadi, 2006). The correlation table and the variance inflation factors are presented in Table A3 in the Appendix.

\section{$4 \quad$ Results}

\subsection{Descriptive statistics}

Table 4 shows interesting differences in firms' knowledge search with respect to innovation success. We conduct significance tests on mean differences between firms with above average usage of certain types of knowledge search compared with the rest. Firms using sciencedriven knowledge search at an above average level exhibit a significantly higher share of sales

5 These variables have frequently been shown to cause heteroscedasticity in this setting (see e. g. Aschhoff and Schmidt, 2006; Czarnitzki and Toole, 2007). 
of both market and firm novelties. In contrast, we do not observe a significant difference for firms engaging predominantly in a supplier-driven knowledge search. A somewhat mixed pattern is revealed by firms that mainly use a market-driven knowledge search. We find a higher share of sales of firm novelties while there is no observable difference in the share of sales of market novelties compared to firms that use a market-driven knowledge search to a below average extent.

Table 4: Descriptive statistics differentiated by type of knowledge search

\begin{tabular}{|c|c|c|c|c|c|c|c|c|c|}
\hline & \multicolumn{2}{|c|}{ All firms } & \multicolumn{3}{|c|}{$\begin{array}{l}\text { Science-driven search } \\
\text { - above average use }\end{array}$} & \multicolumn{2}{|c|}{$\begin{array}{l}\text { Supplier-driven search } \\
\text { - above average use }\end{array}$} & \multicolumn{2}{|c|}{$\begin{array}{l}\text { Market-driven search } \\
\text { - above average use }\end{array}$} \\
\hline & Mean & Std. Dev. & Mea & & Std. Dev. & Mean & Std. Dev. & Mean & Std. Dev. \\
\hline $\begin{array}{l}\text { Share of sales with } \\
\text { market novelties }\end{array}$ & 0.102 & 0.181 & 0.112 & $\star \star \star$ & 0.180 & 0.105 & 0.181 & 0.103 & 0.176 \\
\hline $\begin{array}{l}\text { Share of sales with firm } \\
\text { novelties }\end{array}$ & 0.159 & 0.235 & 0.168 & $\star \star$ & 0.228 & 0.157 & 0.231 & 0.169 & 0.230 \\
\hline $\mathrm{N}$ & 4,933 & & 1,932 & & & 2,522 & & 2,535 & \\
\hline
\end{tabular}

${ }^{*} \mathrm{p}<0.10,{ }^{* *} \mathrm{p}<0.05,{ }^{* * *} \mathrm{p}<0.01$

T-test is computed in comparison to firms using the respective type of search below the average. Descriptive statistics of the full list of variables are presented in Table A1 in the Appendix.

However, firms differ along several dimensions with regard to their choice of type of knowledge search. Table A1 in the Appendix provides descriptive statistics for the full set of variables. Again, we test for significant mean differences between firms with an above average use of a particular type of search compared to their below average counterparts. Common to all types of knowledge search is the fact that they are significantly more likely to be chosen by firms with higher R\&D spending and continuous R\&D activities. Firms with above average search for external knowledge are also significantly larger (in terms of sales), which reflects the availability of resources to develop an active search for external knowledge.

Firms with above average science- and/or market-driven knowledge search are significantly more internationalized (measured as export share of sales) and part of a company group. Process innovators are more likely to focus on science-driven and/or supplier-driven 
knowledge search. With regard to differences across sectoral patterns, we find that sciencedriven knowledge search is significantly more attractive for firms in AKP and MPG. Supplier-driven knowledge search is more intensively used by SIS firms, and market-driven knowledge search again by AKP and MPG firms.

\subsection{Regression results}

Table 5 shows the results of the Tobit model estimations. As outlined previously, we correct the variance in each model to account for the effects of heteroscedasticity and test the outcomes of this correction successfully. We estimate two separate models for each dependent variable. Columns I and II show the estimation results for the full sample. The results in column I show a positive relationship between success with new-to-market innovations, as measured by the share of sales of market novelties, both for science-driven and supplier-driven knowledge search. Thus, we find support for hypotheses 2, which states that science-driven knowledge search propel success with new-to-market innovations rather than with imitations. Column II shows that success with imitations, as measured by the share of sales of firm novelties, is positively affected by market-driven knowledge search while there is no impact on success of new-to-market innovations. This finding supports hypothesis 1 and implies a rejection of hypothesis 3. Supplier-driven knowledge search propels performance with new-to-market innovations but has no significant effect on imitations. 
Table 5: Results of Tobit estimations for the full sample

\begin{tabular}{|c|c|c|}
\hline & $\begin{array}{c}\text { Share of sales of market novelties } \\
\text { I }\end{array}$ & $\begin{array}{c}\text { Share of sales of firm novelties } \\
\text { II }\end{array}$ \\
\hline Science-driven search (scale) & $\begin{array}{l}0.047 * * \\
(0.022)\end{array}$ & $\begin{array}{r}0.022 \\
(0.025)\end{array}$ \\
\hline Supplier-driven search (scale) & $\begin{array}{l}0.046 \text { ** } \\
(0.022)\end{array}$ & $\begin{array}{r}0.015 \\
(0.025)\end{array}$ \\
\hline Market-driven search (scale) & $\begin{array}{r}0.029 \\
(0.019)\end{array}$ & $\begin{array}{l}0.136 * * * \\
(0.022)\end{array}$ \\
\hline R\&D intensity & $\begin{array}{l}0.326 * * * \\
(0.058)\end{array}$ & $\begin{array}{l}0.138 \text { ** } \\
(0.067)\end{array}$ \\
\hline Continous R\&D activities $^{\mathrm{a}}$ & $\begin{array}{l}0.090^{* * *} \\
(0.010)\end{array}$ & $\begin{array}{l}0.036 * * * \\
(0.011)\end{array}$ \\
\hline Export intensity & $\begin{array}{l}0.037 * * \\
(0.017)\end{array}$ & $\begin{array}{r}0.012 \\
(0.019)\end{array}$ \\
\hline Sales $1998(\log )$ & $\begin{array}{r}-0.002 \\
(0.003)\end{array}$ & $\begin{array}{r}0.001 \\
(0.003)\end{array}$ \\
\hline Part of company group ${ }^{a}$ & $\begin{array}{r}0.010 \\
(0.009)\end{array}$ & $\begin{array}{r}-0.001 \\
(0.011)\end{array}$ \\
\hline Process innovation $^{\mathrm{a}}$ & $\begin{array}{r}0.000 \\
(0.009)\end{array}$ & $\begin{array}{l}-0.058^{\star * *} \\
(0.010)\end{array}$ \\
\hline Constant & $\begin{array}{l}-0.177^{* *} \\
(0.046)\end{array}$ & $\begin{array}{l}-0.086 * \\
(0.051)\end{array}$ \\
\hline Country dummies & included & included \\
\hline Industry dummies & included & included \\
\hline Wald-Test on joint significance of industry dummies & $\mathrm{W}(\chi 2(3))=4.99$ & $\mathrm{~W}(\chi 2(3))=4.37$ \\
\hline $\mathrm{R}_{\text {McFadden }}^{2}$ & 0.14 & 0.12 \\
\hline $\mathrm{N}$ & 4,933 & 4,933 \\
\hline LR/Wald chi2 & 306.82 & 288.90 \\
\hline P-value & 0.00 & 0.00 \\
\hline Log likelihood & $-1,872.29$ & $-2,351.57$ \\
\hline LR - Test on heteroscedasticity & $\operatorname{LR}(\chi 2(10))=3745^{\star \star *}$ & 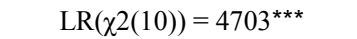 \\
\hline
\end{tabular}

${ }^{*} \mathrm{p}<0.10,{ }^{* \star} \mathrm{p}<0.05,{ }^{* \star \star} \mathrm{p}<0.01$; standard errors in parentheses.

a Dummy variable

Search scales are rescaled between 0 and 1. Coefficients of industry and country dummies are presented in Table A2 in the Appendix. Heteroscedasticity terms include 3 dummies for firm size measured by sales in $1998(\log )\left(0-24^{\text {th }}\right.$ percentile, $25^{\text {th }}-49^{\text {th }}$ percentile, $50^{\text {th }}-74^{\text {th }}$ percentile), country dummies and industry dummies.

Regarding our control variables, we find - as expected - a positive effect of R\&D intensity on both new-to-market innovation and imitation performance. Moreover, performing R\&D continuously has a positive impact on both types of a firm's innovation success. Regarding the remaining control variables in our regression we find that higher export intensity goes hand in hand with higher new-to-market innovation performance while there is no significant effect on imitation success. This may reflect incentives to engage in new-to-market innovation due to high competition pressure in international markets. If firms are process 
innovators they have to allocate limited personnel and financial resources to the development of both new processes and new products. Therefore, innovation success in terms of sales will decrease, which is supported by our findings of negative effects of process innovation. However, this holds only for the models of imitation. No effects can be found for firm size and for a firm being part of a company group.

Table 6 shows the results of the Tobit estimations of the four major sectoral patterns. Several interesting similarities but also differences can be identified among the models. A first striking finding is that a market-driven knowledge search never propels innovation success with new-to-market innovations but only with imitations. This holds for the three sectoral patterns AKP, MPG and PGS. An exception is, however, SIS, which exhibits no significant effect of a market-driven knowledge search at all. Another interesting finding is that both a science-driven and a supplier-driven knowledge search are relevant for new-tomarket innovation performance in AKP and SIS while we find no effect in MPG and PGS. Additionally, a science-driven search strategy also facilitates innovation performance with imitations in AKP. The results for the control variables are largely in line with the findings of the full sample estimations. 
Table 6: Results of the Tobit estimations for the sectoral patterns

\begin{tabular}{|c|c|c|c|c|c|c|c|c|c|c|c|c|c|c|c|c|}
\hline & \multicolumn{4}{|c|}{$\overline{\mathrm{AKP}}$} & \multicolumn{4}{|c|}{$\overline{M P G}$} & \multicolumn{4}{|c|}{ SIS } & \multicolumn{4}{|c|}{ PGS } \\
\hline & \multirow{2}{*}{\multicolumn{2}{|c|}{$\begin{array}{l}\text { Share of sales of } \\
\text { market novelties }\end{array}$}} & \multicolumn{2}{|c|}{$\begin{array}{l}\text { Share of sales of } \\
\text { firm novelties }\end{array}$} & \multicolumn{2}{|c|}{$\begin{array}{l}\text { Share of sales of } \\
\text { market novelties }\end{array}$} & \multicolumn{2}{|c|}{$\begin{array}{l}\text { Share of sales of } \\
\text { firm novelties }\end{array}$} & \multicolumn{2}{|c|}{$\begin{array}{l}\text { Share of sales of } \\
\text { market novelties }\end{array}$} & \multicolumn{2}{|c|}{$\begin{array}{l}\text { Share of sales of } \\
\text { firm novelties }\end{array}$} & \multicolumn{2}{|c|}{$\begin{array}{l}\text { Share of sales of } \\
\text { market novelties }\end{array}$} & \multicolumn{2}{|c|}{$\begin{array}{l}\text { Share of sales of } \\
\text { firm novelties }\end{array}$} \\
\hline & & & IV & & $\mathrm{V}$ & & VI & & VII & & VIII & & IX & & $X$ & \\
\hline Science-driven search (scale) & $\begin{array}{r}0.074 \\
(0.041)\end{array}$ & * & $\begin{array}{r}0.092 \\
(0.047)\end{array}$ & $* *$ & $\begin{array}{r}0.027 \\
(0.035)\end{array}$ & & $\begin{array}{r}-0.052 \\
(0.041)\end{array}$ & & $\begin{array}{r}0.175 \\
(0.060)\end{array}$ & $* * *$ & $\begin{array}{r}0.019 \\
(0.072)\end{array}$ & & $\begin{array}{r}-0.044 \\
(0.042)\end{array}$ & & $\begin{array}{r}0.027 \\
(0.050)\end{array}$ & \\
\hline Supplier-driven search (scale) & $\begin{array}{r}0.105 \\
(0.045)\end{array}$ & $* *$ & $\begin{array}{r}0.037 \\
(0.051)\end{array}$ & & $\begin{array}{r}-0.005 \\
(0.036)\end{array}$ & & $\begin{array}{r}0.018 \\
(0.042)\end{array}$ & & $\begin{array}{r}0.103 \\
(0.049)\end{array}$ & $* *$ & $\begin{array}{r}-0.061 \\
(0.052)\end{array}$ & & $\begin{array}{r}0.037 \\
(0.042)\end{array}$ & & $\begin{array}{r}0.028 \\
(0.049)\end{array}$ & \\
\hline Market-driven search (scale) & $\begin{array}{r}0.065 \\
(0.040)\end{array}$ & & $\begin{array}{r}0.186 \\
(0.045)\end{array}$ & $* * *$ & $\begin{array}{r}0.015 \\
(0.032)\end{array}$ & & $\begin{array}{r}0.142 \\
(0.037)\end{array}$ & $* * *$ & $\begin{array}{r}0.031 \\
(0.043)\end{array}$ & & $\begin{array}{r}0.043 \\
(0.047)\end{array}$ & & $\begin{array}{r}0.000 \\
(0.038)\end{array}$ & & $\begin{array}{r}0.116 \\
(0.043)\end{array}$ & $* * *$ \\
\hline $\mathrm{R} \& \mathrm{D}$ intensity & $\begin{array}{r}0.180 \\
(0.064)\end{array}$ & $* * *$ & $\begin{array}{r}0.109 \\
(0.076)\end{array}$ & & $\begin{array}{r}0.511 \\
(0.169)\end{array}$ & $* * *$ & $\begin{array}{r}0.294 \\
(0.191)\end{array}$ & & $\begin{array}{r}0.992 \\
(0.420)\end{array}$ & $* *$ & $\begin{array}{r}1.220 \\
(0.572)\end{array}$ & $* *$ & $\begin{array}{r}1.397 \\
(0.459)\end{array}$ & $* * *$ & $\begin{array}{r}0.148 \\
(0.563)\end{array}$ & \\
\hline Continuous R\&D activities $^{\mathrm{a}}$ & $\begin{array}{r}0.148 \\
(0.021)\end{array}$ & $* * *$ & $\begin{array}{r}0.028 \\
(0.022)\end{array}$ & & $\begin{array}{r}0.079 \\
(0.016)\end{array}$ & $* * *$ & $\begin{array}{r}0.055 \\
(0.018)\end{array}$ & $* * *$ & $\begin{array}{r}0.039 \\
(0.023)\end{array}$ & * & $\begin{array}{r}0.016 \\
(0.026)\end{array}$ & & $\begin{array}{r}0.064 \\
(0.019)\end{array}$ & $* * *$ & $\begin{array}{r}0.005 \\
(0.022)\end{array}$ & \\
\hline Export intensity & $\begin{array}{r}0.025 \\
(0.033)\end{array}$ & & $\begin{array}{r}0.025 \\
(0.037)\end{array}$ & & $\begin{array}{r}0.051 \\
(0.026)\end{array}$ & $*$ & $\begin{array}{r}0.024 \\
(0.031)\end{array}$ & & $\begin{array}{r}-0.163 \\
(0.065)\end{array}$ & $* *$ & $\begin{array}{r}-0.088 \\
(0.055)\end{array}$ & & $\begin{array}{r}0.097 \\
(0.033)\end{array}$ & $* * *$ & $\begin{array}{r}0.048 \\
(0.035)\end{array}$ & \\
\hline Sales $1998(\log )$ & $\begin{array}{r}-0.017 \\
(0.006)\end{array}$ & $* * *$ & $\begin{array}{r}-0.003 \\
(0.007)\end{array}$ & & $\begin{array}{r}0.002 \\
(0.005)\end{array}$ & & $\begin{array}{r}0.008 \\
(0.006)\end{array}$ & & $\begin{array}{r}0.003 \\
(0.005)\end{array}$ & & $\begin{array}{r}0.007 \\
(0.006)\end{array}$ & & $\begin{array}{r}0.011 \\
(0.007)\end{array}$ & * & $\begin{array}{r}-0.003 \\
(0.007)\end{array}$ & \\
\hline Part of company group ${ }^{a}$ & $\begin{array}{r}0.001 \\
(0.018)\end{array}$ & & $\begin{array}{r}0.012 \\
(0.021)\end{array}$ & & $\begin{array}{r}0.011 \\
(0.016)\end{array}$ & & $\begin{array}{r}-0.036 \\
(0.019)\end{array}$ & * & $\begin{array}{r}-0.007 \\
(0.021)\end{array}$ & & $\begin{array}{r}0.038 \\
(0.023)\end{array}$ & & $\begin{array}{r}0.020 \\
(0.019)\end{array}$ & & $\begin{array}{r}-0.001 \\
(0.022)\end{array}$ & \\
\hline Process innovation ${ }^{\mathrm{a}}$ & $\begin{array}{r}0.002 \\
(0.017)\end{array}$ & & $\begin{array}{r}-0.031 \\
(0.020)\end{array}$ & & $\begin{array}{r}-0.008 \\
(0.015)\end{array}$ & & $\begin{array}{r}-0.042 \\
(0.017)\end{array}$ & $* *$ & $\begin{array}{r}-0.015 \\
(0.022)\end{array}$ & & $\begin{array}{r}-0.068 \\
(0.023)\end{array}$ & $* * *$ & $\begin{array}{r}0.013 \\
(0.019)\end{array}$ & & $\begin{array}{l}-0.087 \\
(0.022)\end{array}$ & $* * *$ \\
\hline Constant & $\begin{array}{r}0.021 \\
(0.087)\end{array}$ & & $\begin{array}{r}-0.081 \\
(0.100)\end{array}$ & & $\begin{array}{r}-0.173 \\
(0.077)\end{array}$ & $* *$ & $\begin{array}{r}-0.169 \\
(0.088)\end{array}$ & * & $\begin{array}{r}-0.233 \\
(0.087)\end{array}$ & $* * *$ & $\begin{array}{r}-0.058 \\
(0.095)\end{array}$ & & $\begin{array}{r}-0.395 \\
(0.117)\end{array}$ & $* * *$ & $\begin{array}{r}0.015 \\
(0.108)\end{array}$ & \\
\hline Country dummies & included & & included & & included & & included & & included & & included & & included & & included & \\
\hline $\mathrm{R}_{\text {McFadden }}^{2}$ & 0.19 & & 0.08 & & 0.12 & & 0.11 & & 0.18 & & 0.20 & & 0.16 & & 0.15 & \\
\hline $\mathrm{N}$ & 1,164 & & 1,164 & & 1,702 & & 1,702 & & 800 & & 800 & & 1,267 & & 1,267 & \\
\hline LR/Wald chi2 & 120.82 & & 55.29 & & 88.90 & & 103.43 & & 43.57 & & 47.91 & & 78.26 & & 86.74 & \\
\hline P-value & 0.00 & & 0.00 & & 0.00 & & 0.00 & & 0.00 & & 0.00 & & 0.00 & & 0.00 & \\
\hline $\begin{array}{l}\text { Log likelihood } \\
\text { LR - Test on heteroscedasticity }\end{array}$ & $\begin{array}{r}-423.56 \\
\operatorname{LR}(\chi 2(7)) \\
847 * * *\end{array}$ & & $\begin{array}{r}-522.82 \\
\operatorname{LR}(\chi 2(7)) \\
1046 * * *\end{array}$ & & $\begin{array}{r}-582.15 \\
\operatorname{LR}(\chi 2(7)) \\
1164 * *\end{array}$ & & $\begin{array}{r}-762.98 \\
\operatorname{LR}(\chi 2(7) \\
1526 * *\end{array}$ & & $\begin{array}{r}-292.0 \\
\operatorname{LR}(\chi 2(7) \\
584 * * *\end{array}$ & & $\begin{array}{r}-335.65 \\
\operatorname{LR}(\chi 2(7)) \\
671^{* * *}\end{array}$ & & $\begin{array}{r}-498.62 \\
\operatorname{LR}(\chi 2(7) \\
997 * * *\end{array}$ & & $\begin{array}{r}-665.34 \\
\operatorname{LR}(\chi 2(7) \\
1331 * *\end{array}$ & \\
\hline
\end{tabular}

${ }^{*} \mathrm{p}<0.10,{ }^{* *} \mathrm{p}<0.05,{ }^{* * *} \mathrm{p}<0.01$; standard errors in parentheses.

Search scales are rescaled between 0 and 1 . Coefficients of country dummies are available from the authors upon request. Heteroscedasticity terms include 3 dummies for firm size measured by sales in 1998 (log) ( 0 -

$24^{\text {th }}$ percentile, $25^{\text {th }}-49^{\text {th }}$ percentile, $50^{\text {th }}-74^{\text {th }}$ percentile) and country dummies. 


\section{Discussion}

We conduct this study to provide a more nuanced perspective on the nature of firms' search for external knowledge and what effects innovation managers can expect from applying them. We argue conceptually that different instances of knowledge search are not homogeneous with regard to the sources they encompass. In that sense, conceptualizations describing knowledge search along the dimensions of breadth and depth (Katila and Ahuja, 2002; Laursen and Salter, 2006) may underestimate the degree of heterogeneity among different knowledge sources. What is more, we integrate two additional elements into the stream of research on open innovation and search strategies. First, we focus on varying degrees of novelty in firms’ open innovation performance. Some knowledge sources can be expected to provide knowledge with a higher degree of novelty providing more opportunities for new-tomarket innovation than others. Second, the nature of innovation activities differs significantly across sectors. In a first step, we test our hypotheses empirically for a comprehensive sample of almost 5,000 firms from five Western European countries and find support for most of them. In a second step, we explore the effects of search on both types of innovation performance across four sectoral patterns of innovation which encompass both manufacturing and service firms. Therefore, conclusions can be drawn with implications for both academic and management audiences.

From a research perspective, we introduce the notion of selectivity in firms' knowledge search. Neither breadth nor depth in a firm's search provide much guidance as to what knowledge sources to combine in a broad knowledge search and what ones to emphasize for depth. We find strong support for our theoretical argument that management should choose a certain direction for a firm's knowledge search. Science-driven, market-driven, and supplierdriven knowledge search differ significantly in the kind of knowledge they can provide and 
the way they can be accessed by the firm. They can therefore not be assumed to be substitutive.

This is reflected in the value they can provide in different sectors and with respect to different degrees of novelty. Several studies highlight the increasing importance of service sectors for most modern economies (e.g. Sirilli and Evangelista, 1998). Moreover, successful innovation in most sectors is increasingly based on a combination of novel products and services instead of a narrow focus on one or the other. However, empirical tests of open innovation knowledge search have primarily focused on manufacturing sectors (Katila and Ahuja, 2002; Laursen and Salter, 2006; Rosenkopf and Nerkar, 2001). We find considerable differences across the four sectoral patterns on which our analysis is based (Castellacci, 2008). It appears that firms can selectively influence their innovation performance depending on targeted search for external knowledge and their sectoral trajectories. In this respect, we find that market-driven knowledge search almost always increases imitation performance. It seems to be very limited in providing highly novel knowledge to firms that would consequently result in new-to-market innovations. Market-driven knowledge search thus includes the danger of over-emphasizing short-term customer needs and imitations of already existing products. Hence, our findings support existing literature (e.g. Slater and Narver, 1998): A primary strategy of avoiding “customer-led” traps of incremental innovation may rest in refocusing a firm's knowledge pool with search directed at leading universities and specialized suppliers.

In contrast to this, firms adopting a science-driven or supplier-driven knowledge search have a good chance to create new-to-market innovations. Advanced knowledge providers can also propel imitation performance by relying on knowledge inputs from science. It seems that in this sectoral pattern the firm's knowledge base needs to be regularly informed by novel 
insights from science to be able to even keep up with competitors and to successfully imitate their products.

From a management perspective at least two implications can be derived. First, not all types of knowledge search provide the basis for new-to-market innovations. Then again, marketdriven knowledge search provides imitations which may still be profitable without entailing the increased risk of the new-to-market innovations. Second, the performance potentials of selective knowledge search for external knowledge are especially high for advanced knowledge providers and supporting infrastructural service sectors. Managers of firms in these sectors should develop deeper ties with leading universities as well as suppliers. These activities require resource commitments in terms of financial investments (e.g. specialized labs) and human resources (e.g. joint research projects, sponsored $\mathrm{PhD}$ projects). Hence, there is a link to the literature on how firms develop ties (Ahuja, 2000; Whittington et al., 2009) which goes far beyond the focus of our analysis. The recognition of industry differences in this study is important for targeted management recommendations because in all other sectors (MPG, PGS), the expected returns of external search cannot outweigh the costs.

Consequently, firms in these sectors are better off fostering their internal R\&D activities when it comes to generating new-to-market products.

\section{Concluding remarks and further research}

Our research benefits from a comprehensive cross-country dataset, which allows us to draw conclusions beyond a certain industry or country context. However, we see room for improvement, which may provide pathways for future research. The effects of investments in R\&D and open innovation networks may reach their full potential over the long run. Hence, longitudinal studies may help to test and substantiate some of our cross-sectional findings. Besides, qualitative studies may provide further in-depth insights into the mechanisms 
underlying the different types of knowledge search. In this respect it would be especially fruitful to explicitly capture the role of functional departments (especially marketing and procurement) and their interaction with the $R \& D$ department when certain knowledge sources are identified, activated and exploited. This may be especially relevant with regard to how legitimacy and trust can be established and how these mechanisms differ across varying knowledge sources. Finally, our investigation is limited to product innovation. Extending this line of research to other types of innovations like organizational or business model innovations may be a fruitful direction for further research.

\section{Acknowledgments}

The authors thank Christian Rammer as well as two anonymous reviewers and the editor for invaluable feedback and discussions. This paper has been produced as part of the Innovation Watch project within the Europe INNOVA Initiative, sponsored by the European Commission. 


\section{References}

Adler, P.S., S.-W. Kwon, 2002. Social Capital: Prospects for a New Concept. Academy of Management Review 27, 17-40.

Ahuja, G., 2000. The Duality of Collaboration: Inducements and Opportunities in the Formation of Interfirm Linkages. Strategic Management Journal 21, 317-343.

Arundel, A., I. Kabla, 1998. What Percentage of Innovations Are Patented? Empirical Estimates for European Firms. Research Policy 27, 127-141.

Aschhoff, B., T. Schmidt, 2006. Empirical Evidence on the Success of R\&D Co-Operation Happy Together? ZEW Discussion Paper No. 06-059, Mannheim.

Asmussen, C.G., T. Pedersen, C. Dhanaraj, 2009. Host-Country Environment and Subsidiary Competence: Extending the Diamond Network Model. Journal of International Business Studies 40, 42-57.

Beise-Zee, M., 2001. Lead Markets. ZEW Economic Studies, Heidelberg/New York.

Bertrand, M., S. Mullainathan, 2001. Do People Mean What They Say? Implications for Subjective Survey Data. American Economic Review, 67-72.

Bloom, N., J. Van Reenen, 2002. Patents, Real Options and Firm Performance. Economic Journal 112, C97-C116.

Breschi, S., F. Malerba, L. Orsenigo, 2000. Technological Regimes and Schumpeterian Patterns of Innovation. Economic Journal 110, 388-410.

Calantone, R.J., J.B. Schmidt, C.A. Di Benedetto, 1997. New Product Activities and Performance: The Moderating Role of Environmental Hostility. Journal of Product Innovation Management 14, 179-189.

Cassiman, B., R. Veugelers, 2006. In Search of Complementarity in the Innovation Strategy: Internal R\&D and External Knowledge Acquisition. Management Science 52, 68-82.

Castellacci, F., 2008. Technological Paradigms, Regimes and Trajectories: Manufacturing and Service Industries in a New Taxonomy of Sectoral Patterns of Innovation. Research Policy 37, 978-994.

Castellacci, F., 2010. Structural Change and the Growth of Industrial Sectors: Empirical Test of a GPT Model. Review of Income and Wealth 56, 449-482.

Chatterjee, S., A.S. Hadi, 2006. Regression Analysis by Example, Wiley-Interscience, New York.

Chatterji, D., 1996. Accessing External Sources of Technology. Technology Management 39, 48-57. 
Chesbrough, H.W., 2003. Open Innovation: The New Imperative for Creating and Profiting from Technology, Harvard Business School Publishing Corporation, Boston.

Cohen, W.M., D.A. Levinthal, 1989. Innovation and Learning: The Two Faces of R\&D. The Economic Journal 99, 569-596.

Cohen, W.M., D.A. Levinthal, 1990. Absorptive Capacity: A New Perspective on Learning and Innovation. Administrative Science Quarterly 35, 128-152.

Cohen, W.M., R.R. Nelson, J.P. Walsh, 2002. Links and Impacts: The Influence of Public Research on Industrial R\&D. Management Science 48, 1-23.

Cowan, R., P.A. David, D. Foray, 2000. The Explicit Economics of Knowledge Codification and Tacitness. Industrial and Corporate Change 9, 211-254.

Criscuolo, C., J.E. Haskel, M.J. Slaughter, 2005. Global Engagement and the Innovation Activities of Firms. NBER Working Paper No. 11479, Cambridge, MA.

Czarnitzki, D., A.A. Toole, 2007. Business R\&D and the Interplay of R\&D Subsidies and Product Market Uncertainty, Review of Industrial Organization 31, 169-181.

Dosi, G., 1982. Technological paradigms and technological trajectories, Research Policy 11, 147-162.

Doz, Y.L., J. Santos, P. Williamson, 2001. From Global to Metanational: How Companies Win in the Knowledge Economy. Harvard Business School Press, Boston.

Dussauge, P., B. Garrette, W. Mitchell, 2000. Learning from Competing Partners: Outcomes and Duration of Scale and Link Alliances in Europe, North America and Asia. Strategic Management Journal 21, 99-126.

Dyer, J.H., N.W. Hatch, 2004. Using Supplier Networks to Learn Faster. MIT Sloan Management Review 45, 57-63.

Ettlie, J.E., 1983. Organizational Policy and Innovation among Suppliers to the Food Processing Sector. Academy of Management Journal 26, 27-44.

Eurostat, 2005. Community Innovation Survey Light (CIS Light). http://europa.eu.int/estatref/info/sdds/de/inn/inn_cisl_sm.htm, Luxemburg.

Frosch, R.A., 1996. The Customer for R\&D Is Always Wrong! Research Technology Management 39, 22-25.

Gallini, N.T., 2002. The Economics of Patents: Lessons from Recent U.S. Patent Reform. Journal of Economic Perspectives 16, 131-155.

Gallouj, F., O. Weinstein, 1997. Innovation in services. Research Policy 26, 537-556.

Galunic, C.D., S. Rodan, 1998. Resource Recombinations in the Firm: Knowledge Structures and the Potential for Schumpeterian. Strategic Management Journal 19, 1193-1201. 
Gatignon, H., M.L. Tushman, W. Smith, P. Anderson (2004), A Structural Approach to Assessing Innovation: Construct Development of Innovation Locus, Type and Characteristics, Management Science 48, 1103-1123.

Gemünden, H., M. Heydebreck, R. Wijnberg, 1992. Technological Interweavement: A Means of Achieving Innovation Success. R\&D Management 22, 359-376.

Greene, W.H., 2002. Econometric Analysis. Prentice Hall, New York.

Griliches, Z., 1990. Patent Statistics as Economic Indicators: A Survey. Journal of Economic Literature 28, 1661-1707.

Hagedoorn, J., M. Cloodt, 2003. Measuring Innovative Performance: Is There an Advantage in Using Multiple Indicators? Research Policy 32, 1365-1379.

Harabi, N., 1995. Appropriability of Technological Innovations - an Empirical Analysis. Research Policy 24, 981-992.

Kaiser, H.F., J. Rice, 1974. Little Jiffy, Mark IV. Educational and Psychological Measurement 34, 111-117.

Kaiser, U., 2002. An Empirical Test of Models Explaining Research Expenditures and Research Cooperation: Evidence for the German Service Sector. International Journal of Industrial Organization 20, 747-774.

Katila, R., 2002. New Product Search over Time: Past Ideas in Their Prime? Academy of Management Journal 45, 995-1010.

Katila, R., G. Ahuja, 2002. Something Old, Something New: A Longitudinal Study of Search Behavior and New Product Introduction. Academy of Management Journal 45, 1183-1194.

Katila, R., E.L. Chen, 2008. Effects of Search Timing on Innovation: The Value of Not Being in Sync with Rivals. Administrative Science Quarterly 53, 593-625.

Ketchen, D.J., G.T.M. Hult, S.F. Slater, 2007. Toward Greater Understanding of Market Orientation and the Resource-Based View. Strategic Management Journal 28, 961-964.

Kleinschmidt, E.J., R.G. Cooper, 1988. The Performance Impact of an International Orientation of Product Innovation. European Journal of Marketing 22, 56-72.

Kogut, R., U. Zander, 1992. Knowledge of the Firm, Combinative Capabilities and the Replication of Technology. Organization Science 33, 383-397.

Kohli, A.K., B.J. Jaworski, 1990. Market Orientation: The Construct, Research Propositions, and Managerial Implications. Journal of Marketing 54, 1-18.

Koput, K.W., 1997. A Chaotic Model of Innovative Search: Some Answers, Many Questions, Organization Science 8, 528-542. 
Kotabe, M., 1990. The Relationship between Offshore Sourcing and Innovativeness of U.S. Multinational Firms: An Empirical Investigation. Journal of International Business Studies 21, 623-638.

Laursen, K., A. Salter, 2006. Open for Innovation: The Role of Openness in Explaining Innovation Performance among U.K. Manufacturing Firms. Strategic Management Journal 27, 131-150.

Leiponen, A., C.E. Helfat, 2010. Location, Decentralization, and Knowledge Sources for Innovation. Organization Science (forthcoming).

Link, A.N., J.T. Scott, 2005. Universities as Partners in U.S. Research Joint Ventures. Research Policy 34, 385-393.

Link, A.N., D.S. Siegel, B. Bozeman, 2007. An Empirical Analysis of the Propensity of Academics to Engage in Informal University Technology Transfer. Industrial and Corporate Change 16, 641-655.

Love, J.H., S. Roper, 2004. Knowledge Sourcing, Innovation and Performance: A Preliminary Analysis of Irish Innovation Panel Data. Aston Business School Working Paper, Birmingham.

Lukas, B.A., O.C. Ferrell, 2000. The Effect of Market Orientation on Product Innovation. Journal of the Academy of Marketing Science 28, 239-247.

Mansfield, E., 1986. Patents and Innovation: An Empirical Study. Management Science 32, 173-181.

March, J.G., Z. Shapira, 1987. Managerial Perspectives on Risk and Risk Taking. Management Science 33, 1404-1418.

Miozzo, M., L. Soete, 2001. Internationalization of Services: A Technological Perspective. Technological Change and Social Forecasting 67, 159-185.

Nelson, R., S. Winter, 1977. In search of a useful theory of innovation. Research Policy 6, 3676.

Nelson, R.R., S.G. Winter, 1982. An Evolutionary Theory of Economic Change. Belknap Press of Harvard University Press, Cambridge, MA.

Ocasio, W., 1997. Towards an Attention-Based View of the Firm. Strategic Management Journal 18, 187-206.

Ojah, K., L. Monplaisir, 2003. Investors' Valuation of Global Product Design and Development. Journal of International Business Studies 34, 457-472.

Paswan, A., D. D'Souza, M.A. Zolfagharian, 2009. Toward a Contextually Anchored Service Innovation Typology. Decision Sciences 40, 513-540.

Pavitt, K., 1984. Sectoral Patterns of Technical Change: Towards a Taxonomy and a Theory. Research Policy 13, 343-373. 
Perkmann, M., K. Walsh, 2007. University-Industry Relationships and Open Innovation: Towards a Research Agenda. International Journal of Management Reviews 9, 259-280.

Polanyi, M. (1967), The Tacit Dimension. Doubleday \& Co., Garden City, NY.

Romer, P.M., 1990. Endogenous Technological Change, Journal of Political Economy 98, 71102.

Rosenkopf, L., A. Nerkar, 2001. Beyond Local Search: Boundary-Spanning, Exploration, and Impact in the Optical Disc Industry. Strategic Management Journal 22, 287-306.

Salomon, R., Jin, B., 2010. Do Leading or Lagging Firms Learn More from Exporting? Strategic Management Journal 31, 1088-1113.

Siegel, D.S., D.A. Waldman, L.E. Atwater, A.N. Link, 2004. Toward a Model of the Effective Transfer of Scientific Knowledge from Academicians to Practitioners: Qualitative Evidence from the Commercialization of University Technologies. Journal of Engineering and Technology Management 21, 115-142.

Sirilli, G., R. Evangelista, 1998. Technological Innovation in Services and Manufacturing: Results from Italian Surveys. Research Policy 27, 881-899.

Slater, S.F., J.C. Narver, 1998. Customer-Led and Market-Oriented: Let's Not Confuse the Two. Strategic Management Journal 19, 1001-1006.

Slater, S.F., J.C. Narver, 1999. Market-Oriented Is More Than Being Customer-Led. Strategic Management Journal 20, 1165-1168.

Slater, S.F., J.C. Narver, 2000. The Positive Effect of a Market Orientation on Business Profitability: A Balanced Replication. Journal of Business Research 48, 69-73.

Sofka, W., C. Grimpe, 2010. Specialized search and innovation performance - evidence across Europe. R\&D Management 40, 310-323.

Subramaniam, M., N. Venkatraman, 2001. Determinants of Transnational New Product Development Capability: Testing the Influence of Transferring and Deploying Tacit Overseas Knowledge. Strategic Management Journal 22, 359-378.

Teece, D.J., G. Pisano, A. Shuen, 1997. Dynamic Capabilities and Strategic Management. Strategic Management Journal 18, 509-533.

Todorova, G., B. Durisin, 2007. Absorptive Capacity: Valuing a Reconceptualization. Academy of Management Review 32, 774-786.

van Echtelt, F.E.A., F. Wynstra, A.J. van Weele, G. Duysters, 2008. Managing Supplier Involvement in New Product Development: A Multiple-Case Study, Journal of Product Innovation Management 25, 180-201.

von Hippel, E., 1988. The Sources of Innovation. Oxford University Press, New York. 
von Zedtwitz, M., O. Gassmann, 2002. Managing Customer Oriented Research. International Journal of Technology Management 24, 165-193.

Whittington, K.B., J. Owen-Smith, W.W. Powell, 2009. Networks, Propinquity, and Innovation in Knowledge-Intensive Industries. Administrative Science Quarterly 54, 90-122. 


\section{Appendix}

Table A1: Descriptive statistics by type of knowledge search

\begin{tabular}{|c|c|c|c|c|c|c|c|c|}
\hline & \multicolumn{2}{|c|}{ All firms } & \multicolumn{2}{|c|}{$\begin{array}{l}\text { Science-driven search - } \\
\text { above average use }\end{array}$} & \multicolumn{2}{|c|}{$\begin{array}{l}\text { Supplier-driven search - } \\
\text { above average use }\end{array}$} & \multicolumn{2}{|c|}{$\begin{array}{l}\text { Market-driven search - } \\
\text { above average use }\end{array}$} \\
\hline & Mean & Std. Dev. & Mean & Std. Dev. & Mean & Std. Dev. & Mean & Std. Dev. \\
\hline $\begin{array}{l}\text { Share of sales with } \\
\text { market novelties }\end{array}$ & 0.102 & 0.181 & $0.112 * \star \star$ & 0.180 & 0.105 & 0.181 & 0.103 & 0.176 \\
\hline $\begin{array}{l}\text { Share of sales with firm } \\
\text { novelties }\end{array}$ & 0.159 & 0.235 & $0.168^{* *}$ & 0.228 & 0.157 & 0.231 & $0.169 * \star *$ & 0.230 \\
\hline $\begin{array}{l}\text { Science-driven search } \\
\text { (scale) }\end{array}$ & 0.000 & 1.000 & $1.048 * \star \star$ & 0.800 & $0.037 * \star \star$ & 1.056 & 0.012 & 1.009 \\
\hline $\begin{array}{l}\text { Supplier-driven search } \\
\text { (scale) }\end{array}$ & 0.000 & 1.000 & 0.126 *** & 0.927 & $0.802^{\star \star \star *}$ & 0.543 & 0.003 & 0.934 \\
\hline $\begin{array}{l}\text { Market-driven search } \\
\text { (scale) }\end{array}$ & 0.000 & 1.000 & 0.120 *** & 0.940 & $0.033^{\star \star}$ & 0.984 & $0.815^{\star \star \star}$ & 0.517 \\
\hline R\&D intensity & 0.024 & 0.083 & $0.039 * \star \star$ & 0.110 & $0.026^{*}$ & 0.088 & 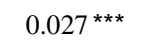 & 0.084 \\
\hline Cont. R\&D activities ${ }^{\mathrm{a}}$ & 0.423 & 0.494 & 0.616 *** & 0.486 & $0.452^{\star \star \star}$ & 0.498 & $0.488^{\star \star \star *}$ & 0.500 \\
\hline Export intensity & 0.212 & 0.280 & $0.267 * \star \star$ & 0.296 & 0.213 & 0.280 & 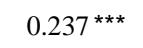 & 0.284 \\
\hline Sales 1998 (log) & 15.952 & 1.970 & 16.461 *** & 2.073 & 15.993 & 1.952 & 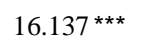 & 1.989 \\
\hline Part of company group ${ }^{a}$ & 0.458 & 0.498 & 0.551 *** & 0.498 & $0.433^{\star \star \star}$ & 0.496 & $0.483^{\star \star \star}$ & 0.500 \\
\hline Process innovation ${ }^{\mathrm{a}}$ & 0.647 & 0.478 & 0.692 *** & 0.462 & $0.687^{\star \star \star}$ & 0.464 & 0.641 & 0.480 \\
\hline Greece $^{\mathrm{a}}$ & 0.067 & 0.251 & $0.038 * \star \star$ & 0.192 & 0.071 & 0.257 & $0.049^{\star \star \star}$ & 0.215 \\
\hline Portugal $^{\mathrm{a}}$ & 0.099 & 0.299 & $0.076^{\star * *}$ & 0.265 & 0.105 & 0.307 & $0.080^{\star \star \star}$ & 0.271 \\
\hline Spain $^{\mathrm{a}}$ & 0.412 & 0.492 & 0.420 & 0.494 & $0.393^{\star \star \star}$ & 0.489 & $0.377^{\star \star \star}$ & 0.485 \\
\hline Germany $^{a}$ & 0.293 & 0.455 & 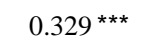 & 0.470 & $0.311^{\star \star \star}$ & 0.463 & $0.370^{\star \star \star}$ & 0.483 \\
\hline Belgium $^{a}$ & 0.129 & 0.335 & 0.136 & 0.343 & $0.119^{\star *}$ & 0.324 & 0.125 & 0.331 \\
\hline $\begin{array}{l}\text { Advanced knowledge } \\
\text { providers }^{\mathrm{a}}\end{array}$ & 0.236 & 0.425 & $0.328 * \star *$ & 0.470 & 0.238 & 0.426 & $0.271^{\star \star \star}$ & 0.445 \\
\hline Mass production goods ${ }^{\mathrm{a}}$ & 0.345 & 0.475 & 0.368 *** & 0.482 & 0.339 & 0.474 & 0.361 ** & 0.480 \\
\hline $\begin{array}{l}\text { Supporting infrastructure } \\
\text { services }^{\mathrm{a}}\end{array}$ & 0.162 & 0.369 & $0.100 * * *$ & 0.300 & 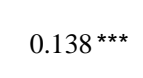 & 0.345 & 0.155 & 0.362 \\
\hline $\begin{array}{l}\text { Personal goods and } \\
\text { services }^{\mathrm{a}}\end{array}$ & 0.257 & 0.437 & $0.204^{\star \star \star}$ & 0.403 & $0.285^{\star \star \star}$ & 0.451 & $0.213^{\star \star *}$ & 0.409 \\
\hline $\mathrm{N}$ & 4,933 & & 1,932 & & 2,522 & & 2,535 & \\
\hline
\end{tabular}


Table A2: Coefficients of country and sectoral pattern dummies of the full sample

\begin{tabular}{|c|c|c|}
\hline & $\begin{array}{c}\text { Share of sales of market novelties } \\
\text { I }\end{array}$ & $\begin{array}{l}\text { Share of sales of firm novelties } \\
\text { II }\end{array}$ \\
\hline Greece $^{\mathrm{a}}$ & $\begin{array}{r}-0.022 \\
(0.037)\end{array}$ & $\begin{array}{l}-0.070^{* * *} \\
(0.031)\end{array}$ \\
\hline Portugal $^{\mathrm{a}}$ & $\begin{array}{l}0.109 \text { *** } \\
(0.022)\end{array}$ & $\begin{array}{l}-0.081^{* * *} \\
(0.022)\end{array}$ \\
\hline Spain $^{\mathrm{a}}$ & $\begin{array}{l}0.085^{* * *} \\
(0.017)\end{array}$ & $\begin{array}{l}0.109^{\star * *} \\
(0.015)\end{array}$ \\
\hline Germany $^{\mathrm{a}}$ & $\begin{array}{l}0.066 \text { *** } \\
(0.017)\end{array}$ & $\begin{array}{l}0.058^{\star * *} \\
(0.014)\end{array}$ \\
\hline Advanced knowledge providers ${ }^{a}$ & $\begin{array}{l}0.028^{* *} \\
(0.014)\end{array}$ & $\begin{array}{l}0.031^{*} \\
(0.016)\end{array}$ \\
\hline Mass production goods ${ }^{\mathrm{a}}$ & $\begin{array}{r}0.020 \\
(0.012)\end{array}$ & $\begin{array}{l}0.024^{*} \\
(0.014)\end{array}$ \\
\hline Supporting infrastructure services ${ }^{\mathrm{a}}$ & $\begin{array}{r}0.003 \\
(0.016)\end{array}$ & $\begin{array}{r}0.011 \\
(0.017)\end{array}$ \\
\hline Wald-Test on joint significance of industry dummies & $\mathrm{W}(\chi 2(3))=4.99$ & $\mathrm{~W}(\chi 2(3))=4.37$ \\
\hline $\mathrm{R}_{\text {McFadden }}^{2}$ & 0.14 & 0.12 \\
\hline $\mathrm{N}$ & 4,933 & 4,933 \\
\hline LR/Wald chi2 & 306.82 & 288.90 \\
\hline P-value & 0.00 & 0.00 \\
\hline Log likelihood & $-1,872.29$ & $-2,351.57$ \\
\hline LR - Test on heteroscedasticity & $\operatorname{LR}(\chi 2(10))=3745^{\star \star *}$ & $\operatorname{LR}(\chi 2(10))=4703^{\star \star \star}$ \\
\hline
\end{tabular}

${ }^{*} \mathrm{p}<0.10,{ }^{* *} \mathrm{p}<0.05,{ }^{* \star *} \mathrm{p}<0.01$

${ }^{\mathrm{a}}$ Dummy variable 


\section{Table A3: Correlation Matrix and Variance Inflation Factors}

\begin{tabular}{|c|c|c|c|c|c|c|c|c|c|c|c|c|c|c|c|c|c|}
\hline & & A & B & $\mathrm{C}$ & $\mathrm{D}$ & $\mathrm{E}$ & $\mathrm{F}$ & G & $\mathrm{H}$ & I & $\mathrm{J}$ & K & $\mathrm{L}$ & M & $\mathrm{N}$ & $\mathrm{O}$ & $\mathrm{P}$ \\
\hline A & Science-driven search (scale) & 1 & & & & & & & & & & & & & & & \\
\hline B & Supplier-driven search (scale) & 0 & 1 & & & & & & & & & & & & & & \\
\hline $\mathrm{C}$ & Market-driven search (scale) & 0 & 0 & 1 & & & & & & & & & & & & & \\
\hline $\mathrm{D}$ & R\&D intensity & 0.218 & 0.019 & 0.041 & 1 & & & & & & & & & & & & \\
\hline $\mathrm{E}$ & Continuous R\&D activities ${ }^{\mathrm{a}}$ & 0.325 & 0.054 & 0.164 & 0.263 & 1 & & & & & & & & & & & \\
\hline $\mathrm{F}$ & Export intensity & 0.145 & 0.003 & 0.109 & 0.011 & 0.266 & 1 & & & & & & & & & & \\
\hline G & Sales $1998(\log )$ & 0.189 & 0.005 & 0.103 & -0.109 & 0.285 & 0.279 & 1 & & & & & & & & & \\
\hline $\mathrm{H}$ & Part of company group ${ }^{a}$ & 0.156 & -0.060 & 0.060 & -0.007 & 0.191 & 0.179 & 0.478 & 1 & & & & & & & & \\
\hline I & Process innovation ${ }^{\mathrm{a}}$ & 0.063 & 0.119 & -0.018 & -0.030 & 0.081 & 0.060 & 0.148 & 0.068 & 1 & & & & & & & \\
\hline $\mathrm{J}$ & Greece $^{\mathrm{a}}$ & -0.082 & 0.045 & -0.097 & -0.078 & -0.094 & -0.203 & -0.184 & -0.140 & 0.022 & 1 & & & & & & \\
\hline K & Portugal $^{\mathrm{a}}$ & -0.058 & 0.029 & -0.089 & -0.073 & -0.111 & 0.048 & -0.079 & -0.039 & 0.100 & -0.089 & 1 & & & & & \\
\hline $\mathrm{L}$ & Spain $^{\mathrm{a}}$ & 0.028 & -0.060 & -0.082 & 0.063 & -0.006 & -0.055 & -0.039 & -0.028 & -0.067 & -0.225 & -0.277 & 1 & & & & \\
\hline M & Germany $^{\mathrm{a}}$ & 0.049 & 0.042 & 0.219 & -0.007 & 0.108 & -0.042 & 0.180 & 0.035 & 0.005 & -0.173 & -0.214 & -0.539 & 1 & & & \\
\hline $\mathrm{N}$ & Advanced knowledge providers ${ }^{\mathrm{a}}$ & 0.194 & -0.007 & 0.095 & 0.285 & 0.186 & 0.033 & -0.151 & -0.009 & -0.073 & -0.024 & -0.106 & -0.050 & 0.098 & 1 & & \\
\hline $\mathrm{O}$ & Mass production goods ${ }^{\mathrm{a}}$ & 0.032 & -0.010 & 0.042 & -0.059 & 0.099 & 0.187 & 0.079 & 0.051 & 0.026 & -0.050 & 0.029 & -0.011 & -0.001 & -0.403 & 1 & \\
\hline $\mathrm{P}$ & Supporting infra-structure services ${ }^{\mathrm{a}}$ & -0.140 & -0.071 & -0.014 & -0.104 & -0.185 & -0.236 & 0.142 & 0.109 & 0.011 & -0.008 & -0.006 & -0.111 & 0.101 & -0.245 & -0.319 & 1 \\
\hline \multicolumn{2}{|c|}{$\overline{\text { VIF }^{b}}$} & 1.22 & 1.04 & 1.10 & 1.21 & 1.41 & 1.37 & 1.68 & 1.36 & 1.06 & 1.63 & 1.69 & 2.73 & 2.59 & 1.77 & 1.64 & 1.58 \\
\hline \multicolumn{2}{|c|}{ Mean VIF } & 1.57 & & & & & & & & & & & & & & & \\
\hline \multicolumn{2}{|l|}{$\mathrm{N}$} & 4,933 & & & & & & & & & & & & & & & \\
\hline
\end{tabular}

${ }^{a}$ Dummy variable

${ }^{6}$ VIF: Variance Inflation Factor 